\title{
The link between iron, metabolic syndrome, and Alzheimer's disease
}

\author{
Grünblatt, E ; Bartl, J ; Riederer, P
}

\begin{abstract}
Both Alzheimer's disease (AD), the most common form of dementia, and type-2 diabetes mellitus (T2DM), a disease associated with metabolic syndrome (MetS), affect a great number of the world population and both have increased prevalence with age. Recently, many studies demonstrated that pre-diabetes, MetS, and T2DM are risk factors in the development of AD and have many common mechanisms. The main focus of studies is the insulin resistance outcome found both in MetS as well as in brains of $\mathrm{AD}$ subjects. However, oxidative stress (OS)-related mechanisms, which are well known to be involved in $\mathrm{AD}$, including mitochondrial dysfunction, elevated iron concentration, reactive oxygen species (ROS), and stress-related enzyme or proteins (e.g. heme oxygenase-1, transferrin, etc.), have not been elucidated in MetS or T2DM brains although OS and iron are involved in the degeneration of the pancreatic islet beta cells. Therefore, this review sets to cover the current literature regarding OS and iron in MetS and T2DM and the similarities to mechanisms in AD both in human subjects as well as in animal models.
\end{abstract}

DOI: https://doi.org/10.1007/s00702-010-0426-3

Posted at the Zurich Open Repository and Archive, University of Zurich ZORA URL: https://doi.org/10.5167/uzh-44581

Journal Article

Published Version

Originally published at:

Grünblatt, E; Bartl, J; Riederer, P (2011). The link between iron, metabolic syndrome, and Alzheimer's disease. Journal of Neural Transmission, 118(3):371-379.

DOI: https://doi.org/10.1007/s00702-010-0426-3 


\title{
The link between iron, metabolic syndrome, and Alzheimer's disease
}

\author{
Edna Grünblatt $\cdot$ Jasmin Bartl $\cdot$ Peter Riederer
}

Received: 22 April 2010/Accepted: 22 May 2010/Published online: 17 June 2010

(C) Springer-Verlag 2010

\begin{abstract}
Both Alzheimer's disease (AD), the most common form of dementia, and type-2 diabetes mellitus (T2DM), a disease associated with metabolic syndrome (MetS), affect a great number of the world population and both have increased prevalence with age. Recently, many studies demonstrated that pre-diabetes, MetS, and T2DM are risk factors in the development of $\mathrm{AD}$ and have many common mechanisms. The main focus of studies is the insulin resistance outcome found both in MetS as well as in brains of AD subjects. However, oxidative stress (OS)related mechanisms, which are well known to be involved in $\mathrm{AD}$, including mitochondrial dysfunction, elevated iron concentration, reactive oxygen species (ROS), and stressrelated enzyme or proteins (e.g. heme oxygenase-1, transferrin, etc.), have not been elucidated in MetS or T2DM brains although OS and iron are involved in the degeneration of the pancreatic islet $\beta$ cells. Therefore, this review sets to cover the current literature regarding OS and iron in MetS and T2DM and the similarities to mechanisms in AD both in human subjects as well as in animal models.
\end{abstract}

E. Grünblatt $(\bowtie)$

Department of Child and Adolescent Psychiatry, University of Zurich, Neumuensterallee 9, 8032 Zurich, Switzerland

e-mail: Gruenblatt_E@klinik.uni-wuerzburg.de

E. Grünblatt · J. Bartl · P. Riederer

Neurochemistry Laboratory, Clinical Neurochemistry, Clinic and Policlinic for Psychiatry, Psychosomatic and Psychotherapy, National Parkinson Foundation Centre of Excellence Laboratories, University of Würzburg, Füchsleinstr. 15, 97080 Würzburg, Germany
Keywords Alzheimer's disease $\cdot \beta$-Amyloid · Diabetes . Heme oxygenase- $1 \cdot$ Insulin resistance $\cdot$ Iron · Metabolic syndrome $\cdot$ Metallothionein $\cdot$ Mitochondria Oxidative stress $\cdot$ Reactive oxygen species (ROS)

\section{Introduction}

Type 2 diabetes mellitus (T2DM) is one of the most important and prevalent chronic diseases. It currently affects 250 million people worldwide, with 6 million new cases reported each year (Cole et al. 2007). This prevalence rises with age from $12 \%$ in people aged $65-70$ to $15 \%$ in people over age 80 (Wild et al. 2004). T2DM is a systemic disease that can damage any organ in the body (Campbell 2009). Resembling diabetes, cognitive dysfunction, especially Alzheimer's disease (AD), represents another serious problem and is rising in prevalence worldwide, especially among the elderly (Alzheimer's 2010). Early onset of T2DM, poor glycemic control and the presence of microand macrovascular disease may interact to produce early cognitive deficits (Awad et al. 2004; Ronnemaa et al. 2008, 2009). Several studies have reported a high risk of $A D$ in patients with T2DM (Ott et al. 1996, 1999; Leibson et al. 1997; Hassing et al. 2004a; Whitmer 2007). In addition, the co-morbid hypertension and overweight were found to be linked to risk of dementia (Hassing et al. 2004b, 2009; Luchsinger and Gustafson 2009; Whitmer et al. 2008).

Many studies suggest that the risk of cognitive decline and neurodegeneration is increased not only in T2DM, but also in patients with pre-diabetes and metabolic syndrome (MetS) (Luchsinger 2008). Individuals with pre-diabetes are defined as those presenting with impaired fasting glucose and/or impaired glucose tolerance (Yaffe et al. 2004), which increases their risk of developing frank T2DM. 
These subjects already present with insulin resistance as a pathophysiological mechanism that is often associated with MetS (Yaffe et al. 2004; Luchsinger 2008). MetS, in turn, is a cluster of interrelated cardiometabolic risk factors including visceral obesity, dyslipidemia (elevated triglycerides and/or low HDL-cholesterol), hypertension, dysglycemia (pre-diabetes or diabetes) (Spalding et al. 2009). MetS was initially defined by the World Health Organization (WHO) in 1998 (Alberti and Zimmet 1998). The prevalence of MetS varies depending on population. In Europe as well as in the United States the prevalence increases with age (Potenza and Mechanick 2009).

It has been suggested that an increase in the plasma concentration of insulin while fasting was associated with $\mathrm{AD}$ both in people with and without diabetes, which suggests that insulin resistance, independent of diabetes, may increase disease risk (Luchsinger et al. 2004; Kuusisto et al. 1997). Consistent reductions in the regional cerebral metabolic rate of glucose were also reported to exist in $\mathrm{AD}$ brain (Fukuyama et al. 1994; Haense et al. 2009; Herholz 2003). However, this diminished glucose utilization was not attributed to an insufficient supply of glucose to the brain, but rather to diminished glucose breakdown in brain tissue caused by a disturbance in the control of glucose utilization at the level of insulin signal transduction (Hoyer 2004). Studies of hippocampal volume revealed a link between insulin resistance and cognitive performance (Rasgon et al. 2009). Indeed, insulin-receptors density is up-regulated in $\mathrm{AD}$ showing an impairment of the insulin signal transduction cascade similar to that seen in T2DM (Frölich et al. 1998). These results suggest that sporadic $\mathrm{AD}$ is the "insulin-resistant brain state" (IRBS) (Hoyer 1998; Salkovic-Petrisic and Lackovic 2005). Insulin resistance seems also to accelerate biological aging by fostering the formation of advanced glycation end-products (AGE) and, consequently, reactive oxygen species (ROS) (Smith et al. 1995; Munch et al. 1997). The relation between insulin and the metabolism of amyloid- $\beta$ peptide $(\mathrm{A} \beta)$ and tau protein hyperphosphorylation in particular has been receiving increasing attention over the past few years (Gasparini and Xu 2003; Craft 2007, 2009).

However, the common mechanism involving iron and oxidative stress (OS) is not yet a focus of attention. One epidemiological study suggested the common etiology in regard to induction of nitrosamine-OS in $\mathrm{AD}, \mathrm{T} 2 \mathrm{DM}$ as well as in non-alcoholic steatohepatitis (de la Monte et al. 2009). Recently, a shift toward linking T2DM and AD is becoming rather mainstream. But some years ago, it was still controversial in regard to the involvement of vascular components, such as AGE and OS in AD (Smith et al. 1996b). Therefore, in this review we attempt to cover the current knowledge with regard to OS and iron involvement both in $\mathrm{AD}$ and in T2DM.

\section{Oxidative stress}

Oxidative stress (OS) is characterized by a compromise in the physiological removal of ROS and/or an increase in their production that results from irreversible damage to biomacromolecules. Oxidative damage of biomacromolecules has been described in the brains of $\mathrm{AD}$ patients: (1) DNA and RNA oxidation is marked by increased levels of 8-hydroxy-2-deoxyguanosine and 8-hydroxyguanosine (Nunomura et al. 1999, 2001); (2) protein oxidation is marked by elevated levels of protein carbonyl and nitration of tyrosine residues (Smith et al. 1996a); (3) lipid peroxidation is marked by high levels of thiobarbituric acid-reactive substances (TBARS), malondialdehyde (MDA), 4-hydroxy-2-nonenal (HNE), and isoprostanes and altered phospholipid composition (Sayre et al. 1997); and (4) modification to sugars is marked by increased glycation and glycoxidation (Smith et al. 1994b). The brain of AD patients, in particular the hippocampus and amygdala, is hallmarked by increased OS as demonstrated by the elevated activities of antioxidant proteins, such as glutathione reductase, glutathione peroxidase, superoxide dismutase, and catalase (Perry et al. 2002).

In T2DM it is debated whether the involvement of mitochondrial dysfunction may cause OS and cell destruction in the pancreatic $\beta$-cells (Sivitz and Yorek 2010). It was reported recently, that redox-sensitive cellular signaling systems play an important role in the development, progressive nature (remodeling), and damaging effects on the $\beta$-cell within the islet of the pancreas (Hayden and Tyagi 2002; Perez-Matute et al. 2009).

\section{Iron accumulation in AD and T2DM}

Iron is an essential component of proteins containing ironsulfur clusters, heme, and diiron-oxo metal centers that are involved in important cellular processes like oxygen transport, mitochondrial respiration, or DNA synthesis (Rausch et al. 1988). Severe iron deficiency will cause growth arrest and cell death. Iron is a transition metal that can serve both as an electron donor and acceptor. In living organisms, iron can be found in its reduced ferrous $\left(\mathrm{Fe}^{2+}\right)$ and its oxidized ferric $\left(\mathrm{Fe}^{3+}\right)$ states. The same chemical properties that make iron a highly versatile component in numerous biological processes can cause toxicity if iron is unshielded. Excess free iron is involved in the Fenton redox reaction which catalyzes the conversion of ROS to the highly reactive hydroxyl radical $(\mathrm{OH} \cdot)$ that will damage DNA, proteins, and lipids. Because iron excess and deficiency are equally detrimental for the cell, regulatory mechanisms have evolved to maintain iron homeostasis 
both at the cellular and at the systemic levels (Hentze et al. 2004).

Iron progressively accumulates in the brain with age (Zecca et al. 2004), which is normally associated to changes in iron metabolism and/or homeostasis. Iron accumulation affects protein modification, misfolding, and aggregation (Hashimoto et al. 1999a, b; Uversky et al. 2001). Besides, it has an important effect on production of radical species and eventually OS (Uversky et al. 2001; Zecca et al. 2004; Hirose et al. 2003).

In $\mathrm{AD}$ it was observed that iron accumulates in the same brain regions that are characterized by amyloid- $\beta$ (A $\beta)$ deposition, such as hippocampus, parietal cortex, and motor cortex (Good et al. 1992; Dedman et al. 1992; Connor et al. 1992b; LeVine 1997). In addition, iron accumulation was also observed in neurons with neurofibrillary tangles (NFT) (Smith et al. 1997). Recently, increased iron both in cortex and in cerebellum of preclinical AD/mild cognitive impaired (MCI) cases was found (Smith et al. 2010). Interestingly, binding of ferric iron to the tau protein precedes the aggregation of hyperphosphorylated tau and the subsequent formation of NFT (Yamamoto et al. 2002). A $\beta$ is a metalloprotein that binds transition metal ions through three histidine residues located in the N-terminal domain (Nakamura et al. 2007; Atwood et al. 2000). Metal binding remotes A $\beta$ aggregation (Bush 2003; House et al. 2004; Loske et al. 2000) and in the absence of metal ions $\mathrm{A} \beta$ is unable to aggregate (Barrow et al. 1992; Faller 2009). A second link between iron homeostasis and $\mathrm{AD}$ is based on the observation that $\mathrm{A} \beta \mathrm{PP}$ expression is iron regulated; $\mathrm{A} \beta \mathrm{PP}$ levels increase upon iron treatment and decrease upon addition of an iron chelator in neuroblastoma cells (Rogers et al. 2002). Interestingly, disease progression of T2DM correlates with amylin deposition, which, similar to $\mathrm{A} \beta$ and tau, undergoes a change in tertiary structure and is finally deposited in insulin-producing pancreatic islet $\beta$-cells (Hoppener et al. 2000). Amylin is also known as islet amyloid polypeptide (IAPP). In a recent study, human amylin induced significant increase in producing ROS via inhibition of mitochondrial complex IV similarly to $\mathrm{A} \beta$ (Lim et al. 2010).

Accumulating evidence suggests that iron plays a pathogenic role in T2DM and its complications, such as microangiopathy and atherosclerosis (Swaminathan et al. 2007; Rajpathak et al. 2009). In addition to the induction of OS, iron may also impede insulin extraction in the liver, impair pancreatic insulin secretion, and interfere with insulin action and glucose uptake in adipocytes. Of note, a reduction in iron overload with either phlebotomy or iron chelation therapy has been shown to reverse or improve glycemic control in T2DM (Swaminathan et al. 2007). Experimental studies have indicated that iron deficiency is related to increased insulin sensitivity in animals (Borel et al. 1993; Farrell et al. 1988), while epidemiological studies have reported an association between iron overload and peripheral insulin resistance (Dandona et al. 1983). Interestingly, elevated body iron stores were recently suggested to be a component of the MetS (Fernandez-Real et al. 1999).

\section{Transferrin and ferritin in AD and T2DM}

Transferrin (for iron mobilization) and ferritin (for iron storage) are well-known proteins involved in iron transport and storage. Transferrin accounts for approximately $0.4 \%$ of the total protein in the brain (Connor et al. 1992b) and is found predominantly in white matter or areas high in white matter (Connor et al. 1987, 1992b). At the cellular level, transferrin is localized mainly in oligodendrocytes (Connor et al. 1990) although neuronal immunostaining has also been reported (Oh et al. 1986). Ferritin levels in the human brain are 10 times higher than transferrin (Connor et al. 1992b). Connor et al. (1992a) demonstrated in AD human brains that transferrin and ferritin in general are found predominantly in oligodendrocytes. Transferrin is homogenously distributed around the senile plaques and is apparently extracellular. In addition, transferrin is found in astrocytes in the cerebral cortical white matter of the Alzheimer's tissue rather than its normal distribution in oligodendrocytes. A robust ferritin immunoreaction accompanies senile plaques and many blood vessels in the Alzheimer's brain tissue. Although many ferritin-positive oligodendrocytes are present in the Alzheimer's tissue, most of the ferritin-containing cells associated with senile plaques and blood vessels are microglia (Connor et al. 1992a).

Alterations in ferritin or transferrin are also reported for T2DM. For example, in a cross-sectional study of Finnish men, it was reported that men with the highest quintile of ferritin had $21.6 \%$ higher levels of insulin and $6.1 \%$ higher levels of glucose (Tuomainen et al. 1997). Other investigators reported that the association of ferritin with insulin sensitivity (assessed by hyperinsulinemic euglycemic clamp) was independent of body mass index (BMI) and other relevant factors (Fernandez-Real et al. 1998, 2007). Similarly, several other cross-sectional studies have also reported an inverse correlation between serum ferritin levels and measures of insulin sensitivity (Fernandez-Real et al. 2007; Haap et al. 2003). In addition to the potential effect of iron on insulin action, insulin may also affect iron metabolism. In vitro data suggest that insulin is capable of redistributing transferrin receptor to the cell surface leading to increased cellular iron uptake in adipose tissue and the liver (Davis et al. 1986; Tanner and Lienhard 1987). This effect of insulin on the up-regulation of iron uptake occurs 
concurrently with its effect on glucose uptake (Tanner and Lienhard 1989). This finding has been further substantiated by experiments in rats which have shown that insulin injection leads to increased serum levels of soluble transferrin receptor (Clairmont and Czech 1990). Thus, hyperinsulinemia in states of insulin resistance may contribute to high circulating soluble transferrin receptor levels. This hypothesis is supported by a recent study among Caucasian men in which a significant inverse correlation between soluble transferrin receptor levels and insulin sensitivity was reported (Fernandez-Real et al. 2007). Moreover, increasing evidence suggests that serum ferritin, a good indicator of body iron stores, is positively associated with MetS (Jehn et al. 2004; Choi et al. 2005).

\section{Metallothionein in AD and T2DM}

Metallothionein (MT) research in the brain has shown that this family of proteins plays a major role in brain physiology (Hidalgo et al. 2001). There are four closely linked $M T$ genes (MT-I-IV) present in rodents (Quaife et al. 1994; Palmiter et al. 1992). Metallothionein-I and metallothionein-II (MT-I\&II) are expressed coordinately in most tissues including those of the CNS (Campagne et al. 2000), while metallothionein-III (MT-III) and metallothionein-IV (MT-IV) show a much more restricted tissue expression (primarily localized in the CNS and stratified squamous epithelia, respectively). There is compelling evidence that MT-I\&II are involved in the response of the brain to damage (Hidalgo et al. 2001), and indeed there is a significant up-regulation of MT-I/MT-II proteins in a number of human neurological diseases, including $\mathrm{AD}$ (Chuah and Getchell 1999; Adlard et al. 1998; Zambenedetti et al. 1998; Hidalgo et al. 2006), while MT-III seems to decrease in AD subjects (Yu et al. 2001).

In T2DM, MT was found to protect islets $\beta$-cells from most kinds of ROS ( $\mathrm{Li}$ et al. 2004a, b).

\section{Heme oxygenase-1 in AD and T2DM}

Heme oxygenases localize within the endoplasmatic reticulum where they function, in association with NADPH cytochrome $\mathrm{P} 450$ reductase, to oxidize heme to biliverdin, free ferrous iron, and carbon monoxide (CO). Two isoforms of heme oxygenase, $\mathrm{HO}-1$ and $\mathrm{HO}-2$, exist in mammals. HO-1 expresses in the brain in few neurons and neuroglia (Baranano and Snyder 2001). It was shown that HO-1 induction, as consequence of OS, may protect cells by enhancing the breakdown of pro-oxidant heme to the radical-scavenging bile pigments, biliverdin, and bilirubin (Baranano and Snyder 2001; Nakagami et al. 1993; Dore et al. 1999). In AD brain, HO-1 protein co-localizes to astrocytes, neurons, NFT, senile plaques, corpora amylacea, ependymocytes, choroid plexus epithelial cells, and some endothelial and vascular smooth muscle cells (Smith et al. 1994a; Schipper et al. 1995). In AD hippocampus an increased immunoreactive HO-1 in astrocytes was found (Schipper et al. 1995). Even in postmortem brain samples of MCI, HO-1 was found to increase (Schipper et al. 2006).

In T2DM it was demonstrated in mononuclear cells, that the HO-1 gene expression was significantly higher in patients compared to controls (Avogaro et al. 2003). Additionally, these authors demonstrated reduction of HO-1 expression after metabolic normalization in some of the patients (Avogaro et al. 2003).

\section{Animal model}

Streptozotocin (STZ) is a naturally produced antibiotic from Streptomyces achromogenes, which is widely used to induce experimental diabetes in mice. Its biological effect lies in the susceptibility of pancreas islets to the drug, which enters the cytoplasm via the glucose transporter GLUT2 (Wang and Gleichmann 1998; Schnedl et al. 1994). Several deleterious effects of STZ have been reported including DNA methylation (Murata et al. 1999), protein modification (Bidasee et al. 2003), and ROS generation (Chen et al. 2001; Gille et al. 2002). It was found that treating STZ-diabetic mice with $\mathrm{ZnSO}_{4}$ significantly up-regulated MT production in pancreatic islets, which in parallel prevented tissue degeneration and STZ-diabetes induction (Ohly et al. 2000). The protective role of MT is also demonstrated by the reduction of STZ-induced DNA damage, degranulation and cell death of pancreatic $\beta$-cells in transgenic mice over-expressing MT-1 upon STZ treatment (Chen et al. 2001). In a recent study, it was reported that treatment of STZ-diabetic mice with $\mathrm{Zn}$ reversed the increased levels of iron and MT caused by STZ in the periphery (e.g. urine, liver, pancreas, and kidney) as well as in the CNS (cerebellum and midbrain) (Beltramini et al. 2006). These authors found again a protective effect of $\mathrm{Zn}$ that was demonstrated both in the periphery as well as in the CNS. In STZ-induced T2DM rats, it was shown that caloric restriction could significantly reduce triglyceride, ROS, and inflammation in the brain (Ugochukwu et al. 2006). The antioxidant enzyme, glutathione peroxidase was reduced as consequence of diabetes induction, while caloric restriction reversed this effect (Ugochukwu et al. 2006).

Considering the presence of insulin and insulin-receptors in the brain, an experimental rat model was developed by using intracerebroventricular (icv) STZ to induce the IRBS (Hoyer et al. 1994). This was found to cause prolonged 
impairment of brain glucose and energy metabolism, decreased choline acetyltransferase levels in the hippocampus as well as impairment in learning and memory (Lannert and Hoyer 1998; Zeevalk et al. 1998; Hoyer et al. 1999, 2000; Hoyer and Lannert 1999; Hoyer 1997). In the last decade, this model was extensively investigated at molecular, pathological, and neurochemical levels and it is notable that many features of this model resemble alterations occurring in AD (de la Monte and Wands 2008; SalkovicPetrisic and Hoyer 2007; Grünblatt et al. 2004, 2006, 2007; Salkovic-Petrisic et al. 2006; Moreira et al. 2004; Shoham et al. 2003, Salkovic-Petrisic and Lackovic 2003, Plaschke et al. 2010; de la Monte and Tong 2009; Tong et al. 2009). Interestingly, it was found that STZ-icv causes decrease of MT-I\&II gene expression in the cortex and striatum, while increase in the cerebellum which might indicate specific sensitivity of cortex and putamen to OS (Grünblatt et al. 2006). Another indication of OS in STZ-icv rats is the findings of significant elevations of malondialdehyde levels and decreased glutathione levels in various brain regions (Sharma and Gupta 2001, 2002; Ishrat et al. 2009).

In an obesity/T2DM mouse model, using high fat diet, Moroz et al. demonstrated a link between AD and T2DM showing that both present insulin resistance in the brain, but still where not fully similar to the neuropathology in AD (Moroz et al. 2008).

In another mice model for T2DM (db/db CBL57) it was found that anti-oxidative defence enzymes, such as superoxide dismutase, catalase, and glutathione- $S$-transferase were significantly lower in the brains than in control animals (Makar et al. 1995). In addition, the amount of polyunsaturated fatty acids was increased in brains of these animals (Makar et al. 1995). These facts point to the susceptibility of these diabetic mice to OS and ROS not only in the periphery, but also in the brain.

Another link between AD pathology and diabetes is the ferric nitrilotriacetate (Fe-NTA)-induced diabetes in rats. (Fe-NTA), an iron chelate, induces carcinoma in the kidneys after intermittent injection and causes diabetes, one of the symptoms of hemochromatosis (Li et al. 1987; Awai et al. 1979). A unique characteristic of Fe-NTA is that it generates free radicals without reducing ferric to ferrous iron (Kawabata et al. 1986), while reduction with $\mathrm{H}_{2} \mathrm{O}_{2}$ induces hydroxyl radicals in a Fenton reaction. In addition, Fe-NTA causes rapid increase in free iron and a higher content in the serum compared with other iron chelates (Liu et al. 1991). Using this model, it was found that iron was accumulating in the cortex and the hypothalamus, rather than in other areas of the brain (Nakatsuka et al. 2009). HO-1 was induced both in the cortex and in the hypothalamus, while muscarinic acetylcholine receptor mRNAs were suppressed in the cortex (Nakatsuka et al. 2009).

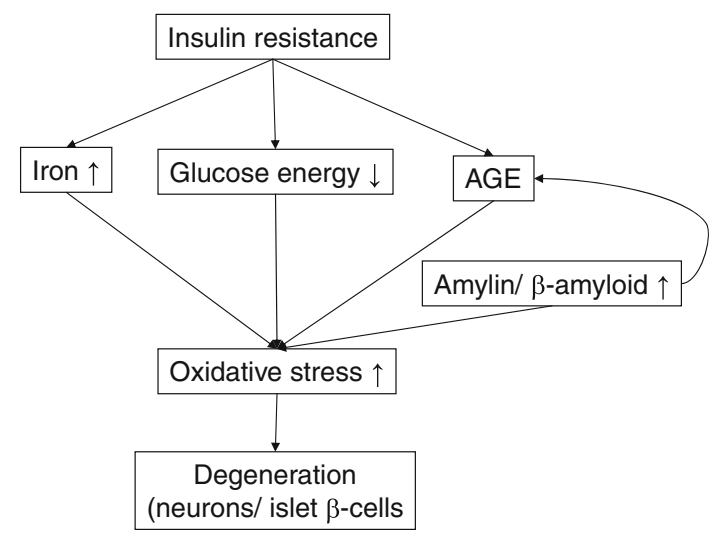

Fig. 1 Common factors involved both in Alzheimer's disease and in metabolic syndrome including type 2 Diabetes mellitus

\section{Conclusion}

From the current literature, it becomes clear that iron involvement both in $\mathrm{AD}$ and in $\mathrm{T} 2 \mathrm{DM}$ is common and causes degeneration of either neurons of islet $\beta$-cells in the pancreas. It is probably not far fetched to hypothesize that MetS causing insulin resistance leads to increase in iron stores in the pancreas as well as in sensitive brain regions which then further may induce T2DM and AD (for the communalities see Fig. 1). The mechanisms of action, which then cause aggregation of amyloid plaques or amylin are strikingly similar in which both cause further toxicity in the cells. Still, the brains of T2DM were very scarcely investigated for OS markers including iron, HO-1, or MT; therefore, it would be of interest linking these alterations known to be involved in AD to T2DM. To do this, further experimental work is essential.

\section{References}

Adlard PA, West AK, Vickers JC (1998) Increased density of metallothionein I/II-immunopositive cortical glial cells in the early stages of Alzheimer's disease. Neurobiol Dis 5:349-356

Alberti KG, Zimmet PZ (1998) Definition, diagnosis and classification of diabetes mellitus and its complications. Part 1: diagnosis and classification of diabetes mellitus provisional report of a WHO consultation. Diabetes Med 15:539-553

Alzheimer's A (2010) 2010 Alzheimer's disease facts and figures. Alzheimers Dement 6:158-194

Atwood CS, Scarpa RC, Huang X, Moir RD, Jones WD, Fairlie DP, Tanzi RE, Bush AI (2000) Characterization of copper interactions with Alzheimer amyloid beta peptides: identification of an attomolar-affinity copper binding site on amyloid beta1-42. J Neurochem 75:1219-1233

Avogaro A, Pagnin E, Calo L (2003) Monocyte NADPH oxidase subunit p22(phox) and inducible hemeoxygenase-1 gene expressions are increased in type II diabetic patients: relationship with oxidative stress. J Clin Endocrinol Metab 88:1753-1759 
Awad N, Gagnon M, Messier C (2004) The relationship between impaired glucose tolerance, type 2 diabetes, and cognitive function. J Clin Exp Neuropsychol 26:1044-1080

Awai M, Narasaki M, Yamanoi Y, Seno S (1979) Induction of diabetes in animals by parenteral administration of ferric nitrilotriacetate. A model of experimental hemochromatosis. Am J Pathol 95:663-673

Baranano DE, Snyder SH (2001) Neural roles for heme oxygenase: contrasts to nitric oxide synthase. Proc Natl Acad Sci USA 98:10996-11002

Barrow CJ, Yasuda A, Kenny PT, Zagorski MG (1992) Solution conformations and aggregational properties of synthetic amyloid beta-peptides of Alzheimer's disease. Analysis of circular dichroism spectra. J Mol Biol 225:1075-1093

Beltramini M, Zambenedetti P, Raso M, IbnlKayat MI, Zatta P (2006) The effect of $\mathrm{Zn}(\mathrm{II})$ and streptozotocin administration in the mouse brain. Brain Res 1109:207-218

Bidasee KR, Nallani K, Yu Y, Cocklin RR, Zhang Y, Wang M, Dincer UD, Besch HR Jr (2003) Chronic diabetes increases advanced glycation end products on cardiac ryanodine receptors/ calcium-release channels. Diabetes 52:1825-1836

Borel MJ, Beard JL, Farrell PA (1993) Hepatic glucose production and insulin sensitivity and responsiveness in iron-deficient anemic rats. Am J Physiol 264:E380-E390

Bush AI (2003) Copper, zinc, and the metallobiology of Alzheimer disease. Alzheimer Dis Assoc Disord 17:147-150

Campagne MV, Thibodeaux H, van Bruggen N, Cairns B, Lowe DG (2000) Increased binding activity at an antioxidant-responsive element in the metallothionein-1 promoter and rapid induction of metallothionein- 1 and -2 in response to cerebral ischemia and reperfusion. J Neurosci 20:5200-5207

Campbell RK (2009) Type 2 diabetes: where we are today: an overview of disease burden, current treatments, and treatment strategies. J Am Pharm Assoc 49(Suppl 1):S3-S9

Chen H, Carlson EC, Pellet L, Moritz JT, Epstein PN (2001) Overexpression of metallothionein in pancreatic beta-cells reduces streptozotocin-induced DNA damage and diabetes. Diabetes 50:2040-2046

Choi KM, Lee KW, Kim HY, Seo JA, Kim SG, Kim NH, Choi DS, Baik SH (2005) Association among serum ferritin, alanine aminotransferase levels, and metabolic syndrome in Korean postmenopausal women. Metabolism 54:1510-1514

Chuah MI, Getchell ML (1999) Metallothionein in olfactory mucosa of Alzheimer's disease patients and apoE-deficient mice. Neuroreport 10:1919-1924

Clairmont KB, Czech MP (1990) Insulin injection increases the levels of serum receptors for transferrin and insulin-like growth factorII/mannose-6-phosphate in intact rats. Endocrinology 127:15681573

Cole AR, Astell A, Green C, Sutherland C (2007) Molecular connexions between dementia and diabetes. Neurosci Biobehav Rev 31:1046-1063

Connor JR, Phillips TM, Lakshman MR, Barron KD, Fine RE, Csiza CK (1987) Regional variation in the levels of transferrin in the CNS of normal and myelin-deficient rats. J Neurochem 49:15231529

Connor JR, Menzies SL, St Martin SM, Mufson EJ (1990) Cellular distribution of transferrin, ferritin, and iron in normal and aged human brains. J Neurosci Res 27:595-611

Connor JR, Menzies SL, St Martin SM, Mufson EJ (1992a) A histochemical study of iron, transferrin, and ferritin in Alzheimer's diseased brains. J Neurosci Res 31:75-83

Connor JR, Snyder BS, Beard JL, Fine RE, Mufson EJ (1992b) Regional distribution of iron and iron-regulatory proteins in the brain in aging and Alzheimer's disease. J Neurosci Res 31:327335
Craft S (2007) Insulin resistance and Alzheimer's disease pathogenesis: potential mechanisms and implications for treatment. Curr Alzheimer Res 4:147-152

Craft S (2009) The role of metabolic disorders in Alzheimer disease and vascular dementia: two roads converged. Arch Neurol 66:300-305

Dandona P, Hussain MA, Varghese Z, Politis D, Flynn DM, Hoffbrand A (1983) Insulin resistance and iron overload. Ann Clin Biochem 20(2):77-79

Davis RJ, Corvera S, Czech MP (1986) Insulin stimulates cellular iron uptake and causes the redistribution of intracellular transferrin receptors to the plasma membrane. J Biol Chem 261:8708-8711

de la Monte SM, Tong M (2009) Mechanisms of nitrosaminemediated neurodegeneration: potential relevance to sporadic Alzheimer's disease. J Alzheimers Dis 17:817-825

de la Monte SM, Wands JR (2008) Alzheimer's disease is type 3 diabetes-evidence reviewed. J Diabetes Sci Technol 2:1101-1113

de la Monte SM, Neusner A, Chu J, Lawton M (2009) Epidemiological trends strongly suggest exposures as etiologic agents in the pathogenesis of sporadic Alzheimer's disease, diabetes mellitus, and non-alcoholic steatohepatitis. J Alzheimers Dis 17:519-529

Dedman DJ, Treffry A, Candy JM, Taylor GA, Morris CM, Bloxham CA, Perry RH, Edwardson JA, Harrison PM (1992) Iron and aluminium in relation to brain ferritin in normal individuals and Alzheimer's-disease and chronic renal-dialysis patients. Biochem J 287(Pt 2):509-514

Dore S, Takahashi M, Ferris CD, Zakhary R, Hester LD, Guastella D, Snyder SH (1999) Bilirubin, formed by activation of heme oxygenase-2, protects neurons against oxidative stress injury. Proc Natl Acad Sci USA 96:2445-2450

Faller P (2009) Copper and zinc binding to amyloid-beta: coordination, dynamics, aggregation, reactivity and metal-ion transfer. Chembiochem 10:2837-2845

Farrell PA, Beard JL, Druckenmiller M (1988) Increased insulin sensitivity in iron-deficient rats. J Nutr 118:1104-1109

Fernandez-Real JM, Ricart-Engel W, Arroyo E, Balanca R, Casamitjana-Abella R, Cabrero D, Fernandez-Castaner M, Soler J (1998) Serum ferritin as a component of the insulin resistance syndrome. Diabetes Care 21:62-68

Fernandez-Real JM, Vendrell J, Baiget M, Gimferrer E, Ricart W (1999) C282Y and H63D mutations of the hemochromatosis candidate gene in type 2 diabetes. Diabetes Care 22:525-526

Fernandez-Real JM, Moreno JM, Lopez-Bermejo A, Chico B, Vendrell J, Ricart W (2007) Circulating soluble transferrin receptor according to glucose tolerance status and insulin sensitivity. Diabetes Care 30:604-608

Frölich L, Blum-Degen D, Bernstein HG et al (1998) Brain insulin and insulin receptors in aging and sporadic Alzheimer's disease. J Neural Transm 105:423-438

Fukuyama H, Ogawa M, Yamauchi H, Yamaguchi S, Kimura J, Yonekura Y, Konishi J (1994) Altered cerebral energy metabolism in Alzheimer's disease: a PET study. J Nucl Med 35:1-6

Gasparini L, Xu H (2003) Potential roles of insulin and IGF-1 in Alzheimer's disease. Trends Neurosci 26:404-406

Gille L, Schott-Ohly P, Friesen N, Schulte im Walde S, Udilova N, Nowl H, Gleichmann H (2002) Generation of hydroxyl radicals mediated by streptozotocin in pancreatic islets of mice in vitro. Pharmacol Toxicol 90:317-326

Good PF, Perl DP, Bierer LM, Schmeidler J (1992) Selective accumulation of aluminum and iron in the neurofibrillary tangles of Alzheimer's disease: a laser microprobe (LAMMA) study. Ann Neurol 31:286-292

Grünblatt E, Hoyer S, Riederer P (2004) Gene expression profile in streptozotocin rat model for sporadic Alzheimer's disease. J Neural Transm 111:367-386 
Grünblatt E, Koutsilieri E, Hoyer S, Riederer P (2006) Gene expression alterations in brain areas of intracerebroventricular streptozotocin treated rat. J Alzheimers Dis 9:261-271

Grünblatt E, Salkovic-Petrisic M, Osmanovic J, Riederer P, Hoyer S (2007) Brain insulin system dysfunction in streptozotocin intracerebroventricularly treated rats generates hyperphosphorylated tau protein. J Neurochem 101:757-770

Haap M, Fritsche A, Mensing HJ, Haring HU, Stumvoll M (2003) Association of high serum ferritin concentration with glucose intolerance and insulin resistance in healthy people. Ann Intern Med 139:869-871

Haense C, Herholz K, Jagust WJ, Heiss WD (2009) Performance of FDG PET for detection of Alzheimer's disease in two independent multicentre samples (NEST-DD and ADNI). Dement Geriatr Cogn Disord 28:259-266

Hashimoto M, Hsu LJ, Xia Y, Takeda A, Sisk A, Sundsmo M, Masliah E (1999a) Oxidative stress induces amyloid-like aggregate formation of NACP/alpha-synuclein in vitro. Neuroreport 10:717-721

Hashimoto M, Takeda A, Hsu LJ, Takenouchi T, Masliah E (1999b) Role of cytochrome $\mathrm{c}$ as a stimulator of alpha-synuclein aggregation in Lewy body disease. J Biol Chem 274:28849-28852

Hassing LB, Grant MD, Hofer SM, Pedersen NL, Nilsson SE, Berg S, McClearn G, Johansson B (2004a) Type 2 diabetes mellitus contributes to cognitive decline in old age: a longitudinal population-based study. J Int Neuropsychol Soc 10:599-607

Hassing LB, Hofer SM, Nilsson SE, Berg S, Pedersen NL, McClearn G, Johansson B (2004b) Comorbid type 2 diabetes mellitus and hypertension exacerbates cognitive decline: evidence from a longitudinal study. Age Ageing 33:355-361

Hassing LB, Dahl AK, Thorvaldsson V, Berg S, Gatz M, Pedersen NL, Johansson B (2009) Overweight in midlife and risk of dementia: a 40-year follow-up study. Int J Obes (Lond) 33:893898

Hayden MR, Tyagi SC (2002) Islet redox stress: the manifold toxicities of insulin resistance, metabolic syndrome and amylin derived islet amyloid in type 2 diabetes mellitus. JOP 3:86-108

Hentze MW, Muckenthaler MU, Andrews NC (2004) Balancing acts: molecular control of mammalian iron metabolism. Cell 117:285297

Herholz K (2003) PET studies in dementia. Ann Nucl Med 17:79-89

Hidalgo J, Aschner M, Zatta P, Vasak M (2001) Roles of the metallothionein family of proteins in the central nervous system. Brain Res Bull 55:133-145

Hidalgo J, Penkowa M, Espejo C et al (2006) Expression of metallothionein-I, -II, and -III in Alzheimer disease and animal models of neuroinflammation. Exp Biol Med (Maywood) 231:1450-1458

Hirose W, Ikematsu K, Tsuda R (2003) Age-associated increases in heme oxygenase- 1 and ferritin immunoreactivity in the autopsied brain. Leg Med (Tokyo) 5(Suppl 1):S360-S366

Hoppener JW, Ahren B, Lips CJ (2000) Islet amyloid and type 2 diabetes mellitus. N Engl J Med 343:411-419

House E, Collingwood J, Khan A, Korchazkina O, Berthon G, Exley C (2004) Aluminium, iron, zinc and copper influence the in vitro formation of amyloid fibrils of Abeta42 in a manner which may have consequences for metal chelation therapy in Alzheimer's disease. J Alzheimers Dis 6:291-301

Hoyer S (1997) Models of Alzheimer's disease: cellular and molecular aspects. J Neural Transm Suppl 49:11-21

Hoyer S (1998) Is sporadic Alzheimer disease the brain type of noninsulin dependent diabetes mellitus? A challenging hypothesis. J Neural Transm 105:415-422

Hoyer S (2004) Glucose metabolism and insulin receptor signal transduction in Alzheimer disease. Eur J Pharmacol 490:115125
Hoyer S, Lannert H (1999) Inhibition of the neuronal insulin receptor causes Alzheimer-like disturbances in oxidative/energy brain metabolism and in behavior in adult rats. Ann N Y Acad Sci 893:301-303

Hoyer S, Muller D, Plaschke K (1994) Desensitization of brain insulin receptor Effect on glucose/energy and related metabolism. J Neural Transm Suppl 44:259-268

Hoyer S, Lannert H, Noldner M, Chatterjee SS (1999) Damaged neuronal energy metabolism and behavior are improved by Ginkgo biloba extract (EGb 761). J Neural Transm 106:11711188

Hoyer S, Lee SK, Loffler T, Schliebs R (2000) Inhibition of the neuronal insulin receptor. An in vivo model for sporadic Alzheimer disease? Ann N Y Acad Sci 920:256-258

Ishrat T, Parveen K, Khan MM, Khuwaja G, Khan MB, Yousuf S, Ahmad A, Shrivastav P, Islam F (2009) Selenium prevents cognitive decline and oxidative damage in rat model of streptozotocin-induced experimental dementia of Alzheimer's type. Brain Res 1281:117-127

Jehn M, Clark JM, Guallar E (2004) Serum ferritin and risk of the metabolic syndrome in U.S. adults. Diabetes Care 27:24222428

Kawabata T, Awai M, Kohno M (1986) Generation of active oxygen species by iron nitrilotriacetate (Fe-NTA). Acta Med Okayama 40:163-173

Kuusisto J, Koivisto K, Mykkanen L et al (1997) Association between features of the insulin resistance syndrome and Alzheimer's disease independently of apolipoprotein E4 phenotype: cross sectional population based study. Bmj 315:1045-1049

Lannert H, Hoyer S (1998) Intracerebroventricular administration of streptozotocin causes long-term diminutions in learning and memory abilities and in cerebral energy metabolism in adult rats. Behav Neurosci 112:1199-1208

Leibson CL, Rocca WA, Hanson VA, Cha R, Kokmen E, O'Brien PC, Palumbo PJ (1997) Risk of dementia among persons with diabetes mellitus: a population-based cohort study. Am J Epidemiol 145:301-308

LeVine SM (1997) Iron deposits in multiple sclerosis and Alzheimer's disease brains. Brain Res 760:298-303

Li JL, Okada S, Hamazaki S, Ebina Y, Midorikawa O (1987) Subacute nephrotoxicity and induction of renal cell carcinoma in mice treated with ferric nitrilotriacetate. Cancer Res 47:18671869

Li X, Chen H, Epstein PN (2004a) Metallothionein protects islets from hypoxia and extends islet graft survival by scavenging most kinds of reactive oxygen species. J Biol Chem 279:765-771

Li X, Zhou ZG, Huang G, Yan X, Yang L, Chen XY, Wang JP (2004b) Optimal cutoff point of glutamate decarboxylase antibody titers in differentiating two subtypes of adult-onset latent autoimmune diabetes. Ann N Y Acad Sci 1037:122-126

Lim YA, Rhein V, Baysang G et al (2010) Abeta and human amylin share a common toxicity pathway via mitochondrial dysfunction. Proteomics 10:1621-1633

Liu M, Okada S, Kawabata T (1991) Radical-promoting "free" iron level in the serum of rats treated with ferric nitrilotriacetate: comparison with other iron chelate complexes. Acta Med Okayama 45:401-408

Loske C, Gerdemann A, Schepl W, Wycislo M, Schinzel R, Palm D, Riederer P, Munch G (2000) Transition metal-mediated glycoxidation accelerates cross-linking of beta-amyloid peptide. Eur J Biochem 267:4171-4178

Luchsinger JA (2008) Adiposity, hyperinsulinemia, diabetes and Alzheimer's disease: an epidemiological perspective. Eur J Pharmacol 585:119-129

Luchsinger JA, Gustafson DR (2009) Adiposity, type 2 diabetes, and Alzheimer's disease. J Alzheimers Dis 16:693-704 
Luchsinger JA, Tang MX, Shea S, Mayeux R (2004) Hyperinsulinemia and risk of Alzheimer disease. Neurology 63:1187-1192

Makar TK, Rimpel-Lamhaouar K, Abraham DG, Gokhale VS, Cooper AJ (1995) Antioxidant defense systems in the brains of type II diabetic mice. J Neurochem 65:287-291

Moreira PI, Santos MS, Moreno AM, Proenca T, Seica R, Oliveira CR (2004) Effect of streptozotocin-induced diabetes on rat brain mitochondria. J Neuroendocrinol 16:32-38

Moroz N, Tong M, Longato L, Xu H, de la Monte SM (2008) Limited Alzheimer-type neurodegeneration in experimental obesity and type 2 diabetes mellitus. J Alzheimers Dis 15:29-44

Munch G, Thome J, Foley P, Schinzel R, Riederer P (1997) Advanced glycation endproducts in ageing and Alzheimer's disease. Brain Res Brain Res Rev 23:134-143

Murata M, Harada M, Kato S et al (1999) Peripheral blood stem cell mobilization and apheresis: analysis of adverse events in 94 normal donors. Bone Marrow Transplant 24:1065-1071

Nakagami T, Toyomura K, Kinoshita T, Morisawa S (1993) A beneficial role of bile pigments as an endogenous tissue protector: anti-complement effects of biliverdin and conjugated bilirubin. Biochim Biophys Acta 1158:189-193

Nakamura M, Shishido N, Nunomura A, Smith MA, Perry G, Hayashi Y, Nakayama K, Hayashi T (2007) Three histidine residues of amyloid-beta peptide control the redox activity of copper and iron. Biochemistry 46:12737-12743

Nakatsuka I, Maeda S, Andoh T, Hayashi Y, Mizuno R, Higuchi H, Miyawaki $\mathrm{T}$ (2009) Oxidative changes in the rat brain by intraperitoneal injection of ferric nitrilotriacetate. Redox Rep 14:109-114

Nunomura A, Perry G, Pappolla MA, Wade R, Hirai K, Chiba S, Smith MA (1999) RNA oxidation is a prominent feature of vulnerable neurons in Alzheimer's disease. J Neurosci 19:1959_ 1964

Nunomura A, Perry G, Aliev G et al (2001) Oxidative damage is the earliest event in Alzheimer disease. J Neuropathol Exp Neurol 60:759-767

Oh TH, Markelonis GJ, Royal GM, Bregman BS (1986) Immunocytochemical distribution of transferrin and its receptor in the developing chicken nervous system. Brain Res 395:207-220

Ohly P, Dohle C, Abel J, Seissler J, Gleichmann H (2000) Zinc sulphate induces metallothionein in pancreatic islets of mice and protects against diabetes induced by multiple low doses of streptozotocin. Diabetologia 43:1020-1030

Ott A, Stolk RP, Hofman A, van Harskamp F, Grobbee DE, Breteler MM (1996) Association of diabetes mellitus and dementia: the Rotterdam Study. Diabetologia 39:1392-1397

Ott A, Stolk RP, van Harskamp F, Pols HA, Hofman A, Breteler MM (1999) Diabetes mellitus and the risk of dementia: The Rotterdam Study. Neurology 53:1937-1942

Palmiter RD, Findley SD, Whitmore TE, Durnam DM (1992) MT-III, a brain-specific member of the metallothionein gene family. Proc Natl Acad Sci USA 89:6333-6337

Perez-Matute P, Zulet MA, Martinez JA (2009) Reactive species and diabetes: counteracting oxidative stress to improve health. Curr Opin Pharmacol 9:771-779

Perry G, Cash AD, Smith MA (2002) Alzheimer disease and oxidative stress. J Biomed Biotechnol 2:120-123

Plaschke K, Kopitz J, Siegelin M, Schliebs R, Salkovic-Petrisic M, Riederer P, Hoyer S (2010) Insulin-resistant brain state after intracerebroventricular streptozotocin injection exacerbates Alzheimer-like changes in Tg2576 AbetaPP-overexpressing mice. J Alzheimers Dis 19(2):691-704

Potenza MV, Mechanick JI (2009) The metabolic syndrome: definition, global impact, and pathophysiology. Nutr Clin Pract 24:560-577
Quaife CJ, Findley SD, Erickson JC, Froelick GJ, Kelly EJ, Zambrowicz BP, Palmiter RD (1994) Induction of a new metallothionein isoform (MT-IV) occurs during differentiation of stratified squamous epithelia. Biochemistry 33:7250-7259

Rajpathak SN, Crandall JP, Wylie-Rosett J, Kabat GC, Rohan TE, Hu FB (2009) The role of iron in type 2 diabetes in humans. Biochim Biophys Acta 1790:671-681

Rasgon NL, Kenna HA, Wroolie TE et al (2009) Insulin resistance and hippocampal volume in women at risk for Alzheimer's disease. Neurobiol Aging (EPub Date 2009/12/25)

Rausch WD, Hirata Y, Nagatsu T, Riederer P, Jellinger K (1988) Tyrosine hydroxylase activity in caudate nucleus from Parkinson's disease: effects of iron and phosphorylating agents. J Neurochem 50:202-208

Rogers JT, Randall JD, Cahill CM et al (2002) An iron-responsive element type II in the 5'-untranslated region of the Alzheimer's amyloid precursor protein transcript. J Biol Chem 277:4551845528

Ronnemaa E, Zethelius B, Sundelof J, Sundstrom J, DegermanGunnarsson M, Berne C, Lannfelt L, Kilander L (2008) Impaired insulin secretion increases the risk of Alzheimer disease. Neurology 71:1065-1071

Ronnemaa E, Zethelius B, Sundelof J, Sundstrom J, DegermanGunnarsson M, Lannfelt L, Berne C, Kilander L (2009) Glucose metabolism and the risk of Alzheimer's disease and dementia: a population-based 12 year follow-up study in 71-year-old men. Diabetologia 52:1504-1510

Salkovic-Petrisic M, Hoyer S (2007) Central insulin resistance as a trigger for sporadic Alzheimer-like pathology: an experimental approach. J Neural Transm Suppl 72:217-233

Salkovic-Petrisic M, Lackovic Z (2003) Intracerebroventricular administration of betacytotoxics alters expression of brain monoamine transporter genes. J Neural Transm 110:15-29

Salkovic-Petrisic M, Lackovic Z (2005) Insulin resistant brain state and its link to diabetes mellitus. Period Biol 107:137-146

Salkovic-Petrisic M, Tribl F, Schmidt M, Hoyer S, Riederer P (2006) Alzheimer-like changes in protein kinase $\mathrm{B}$ and glycogen synthase kinase- 3 in rat frontal cortex and hippocampus after damage to the insulin signalling pathway. J Neurochem 96:1005-1015

Sayre LM, Zelasko DA, Harris PL, Perry G, Salomon RG, Smith MA (1997) 4-Hydroxynonenal-derived advanced lipid peroxidation end products are increased in Alzheimer's disease. J Neurochem 68:2092-2097

Schipper HM, Cisse S, Stopa EG (1995) Expression of heme oxygenase-1 in the senescent and Alzheimer-diseased brain. Ann Neurol 37:758-768

Schipper HM, Bennett DA, Liberman A, Bienias JL, Schneider JA, Kelly J, Arvanitakis Z (2006) Glial heme oxygenase-1 expression in Alzheimer disease and mild cognitive impairment. Neurobiol Aging 27:252-261

Schnedl WJ, Ferber S, Johnson JH, Newgard CB (1994) STZ transport and cytotoxicity. Specific enhancement in GLUT2expressing cells. Diabetes 43:1326-1333

Sharma M, Gupta YK (2001) Intracerebroventricular injection of streptozotocin in rats produces both oxidative stress in the brain and cognitive impairment. Life Sci 68:1021-1029

Sharma M, Gupta YK (2002) Chronic treatment with trans resveratrol prevents intracerebroventricular streptozotocin induced cognitive impairment and oxidative stress in rats. Life Sci 71:2489 2498

Shoham S, Bejar C, Kovalev E, Weinstock M (2003) Intracerebroventricular injection of streptozotocin causes neurotoxicity to myelin that contributes to spatial memory deficits in rats. Exp Neurol 184:1043-1052 
Sivitz WI, Yorek MA (2010) Mitochondrial dysfunction in diabetes: from molecular mechanisms to functional significance and therapeutic opportunities. Antioxid Redox Signal 12:537-577

Smith MA, Kutty RK, Richey PL, Yan SD, Stern D, Chader GJ, Wiggert B, Petersen RB, Perry G (1994a) Heme oxygenase-1 is associated with the neurofibrillary pathology of Alzheimer's disease. Am J Pathol 145:42-47

Smith MA, Taneda S, Richey PL, Miyata S, Yan SD, Stern D, Sayre LM, Monnier VM, Perry G (1994b) Advanced Maillard reaction end products are associated with Alzheimer disease pathology. Proc Natl Acad Sci USA 91:5710-5714

Smith MA, Sayre LM, Monnier VM, Perry G (1995) Radical AGEing in Alzheimer's disease. Trends Neurosci 18:172-176

Smith MA, Perry G, Richey PL, Sayre LM, Anderson VE, Beal MF, Kowall N (1996a) Oxidative damage in Alzheimer's. Nature 382:120-121

Smith MA, Sayre LM, Perry G (1996b) Diabetes mellitus and Alzheimer's disease: glycation as a biochemical link. Diabetologia 39:247

Smith MA, Harris PL, Sayre LM, Perry G (1997) Iron accumulation in Alzheimer disease is a source of redox-generated free radicals. Proc Natl Acad Sci USA 94:9866-9868

Smith MA, Zhu X, Tabaton M et al (2010) Increased iron and free radical generation in preclinical Alzheimer disease and mild cognitive impairment. J Alzheimers Dis 19:363-372

Spalding A, Kernan J, Lockette W (2009) The metabolic syndrome: a modern plague spread by modern technology. J Clin Hypertens (Greenwich) 11:755-760

Swaminathan S, Fonseca VA, Alam MG, Shah SV (2007) The role of iron in diabetes and its complications. Diabetes Care 30:19261933

Tanner LI, Lienhard GE (1987) Insulin elicits a redistribution of transferrin receptors in 3T3-L1 adipocytes through an increase in the rate constant for receptor externalization. J Biol Chem 262:8975-8980

Tanner LI, Lienhard GE (1989) Localization of transferrin receptors and insulin-like growth factor II receptors in vesicles from 3T3L1 adipocytes that contain intracellular glucose transporters. J Cell Biol 108:1537-1545

Tong M, Neusner A, Longato L, Lawton M, Wands JR, de la Monte SM (2009) Nitrosamine exposure causes insulin resistance diseases: relevance to type 2 diabetes mellitus, non-alcoholic steatohepatitis, and Alzheimer's disease. J Alzheimers Dis $17: 827-844$

Tuomainen TP, Nyyssonen K, Salonen R, Tervahauta A, Korpela H, Lakka T, Kaplan GA, Salonen JT (1997) Body iron stores are associated with serum insulin and blood glucose concentrations. Population study in 1,013 eastern Finnish men. Diabetes Care 20:426-428

Ugochukwu NH, Mukes JD, Figgers CL (2006) Ameliorative effects of dietary caloric restriction on oxidative stress and inflammation in the brain of streptozotocin-induced diabetic rats. Clin Chim Acta 370:165-173

Uversky VN, Li J, Fink AL (2001) Metal-triggered structural transformations, aggregation, and fibrillation of human alphasynuclein. A possible molecular NK between Parkinson's disease and heavy metal exposure. J Biol Chem 276:4428444296

Wang Z, Gleichmann H (1998) GLUT2 in pancreatic islets: crucial target molecule in diabetes induced with multiple low doses of streptozotocin in mice. Diabetes 47:50-56

Whitmer RA (2007) Type 2 diabetes and risk of cognitive impairment and dementia. Curr Neurol Neurosci Rep 7:373-380

Whitmer RA, Gustafson DR, Barrett-Connor E, Haan MN, Gunderson EP, Yaffe K (2008) Central obesity and increased risk of dementia more than three decades later. Neurology 71:10571064

Wild S, Roglic G, Green A, Sicree R, King H (2004) Global prevalence of diabetes: estimates for the year 2000 and projections for 2030. Diabetes Care 27:1047-1053

Yaffe K, Blackwell T, Kanaya AM, Davidowitz N, Barrett-Connor E, Krueger K (2004) Diabetes, impaired fasting glucose, and development of cognitive impairment in older women. Neurology 63:658-663

Yamamoto A, Shin RW, Hasegawa K, Naiki H, Sato H, Yoshimasu F, Kitamoto T (2002) Iron (III) induces aggregation of hyperphosphorylated tau and its reduction to iron (II) reverses the aggregation: implications in the formation of neurofibrillary tangles of Alzheimer's disease. J Neurochem 82:1137-1147

Yu WH, Lukiw WJ, Bergeron C, Niznik HB, Fraser PE (2001) Metallothionein III is reduced in Alzheimer's disease. Brain Res 894:37-45

Zambenedetti P, Giordano R, Zatta P (1998) Metallothioneins are highly expressed in astrocytes and microcapillaries in Alzheimer's disease. J Chem Neuroanat 15:21-26

Zecca L, Youdim MB, Riederer P, Connor JR, Crichton RR (2004) Iron, brain ageing and neurodegenerative disorders. Nat Rev Neurosci 5:863-873

Zeevalk GD, Bernard LP, Sinha C, Ehrhart J, Nicklas WJ (1998) Excitotoxicity and oxidative stress during inhibition of energy metabolism. Dev Neurosci 20:444-453 